\title{
Reintroduction of Groenlandia densa (L.) Fourr. - experiences and suggestions
}

\author{
Mariola Wróbel $^{1 *}$, Artur Furdyna ${ }^{2} \&$ Tymoteusz Miller ${ }^{3}$
}

\begin{abstract}
${ }^{1}$ Department of Landscape Architecture, West Pomeranian University of Technology in Szczecin, Słowackiego 17, 71-434 Szczecin, Poland; ORCID: https://orcid.org/ 0000-0002-4814-1393

${ }^{2}$ Regional Directorate for Environmental Protection in Szczecin, Teofila Firlika 20, 71-637 Szczecin, Poland; ORCID: https://orcid.org/ 0000-0001-5746-2802

${ }^{3}$ University of Szczecin, Institute of Marine and Environmental Sciences, Wąska 13, 71-412 Szczecin, Poland; ORCID: https://orcid.org/ 0000-0002-5962-5334

* corresponding author (e-mail: mariola.wrobel@zut.edu.pl)
\end{abstract}

\begin{abstract}
Groenlandia densa (L.) Fourr. is a native species in Poland of evergreen hydromacrophyte occurring in water-sources or groundwater-fed watercourses. It is a critically endangered taxon which requires active protection. To increase the chance of preserving $G$. densa population in Western Pomerania, this plant was introduced to the Grabowa and Radew river systems in the Natura 2000 areas PLH 320022 "Radew, Chociela and Chotla Valley" and PLH 320003 "Grabowa Valley", on a total of 33 sites. In the Radew and its tributaries (Chociel, Zgniła Struga), 6 out of 20 sites were maintained, where reintroduction was successful, while in the Grabowa and its tributaries (Błotnica, Biegała), only 3 out of 13 reintroduction sites survived, and reintroduction in the remaining ones did not bring expected results. Favorable conditions for $G$. densa were found in initial stages of Beruletum submersae Roll 1938 plant community.
\end{abstract}

Key words: Groenlandia densa, critically endangered species, plant reintroduction, water-crowfoot habitats, riverine habitats, Ranunculion fluitantis

\section{Introduction}

Lowland water-crowfoot rivers are located in areas with diversified geomorphology typical of the young glacial landscape of north-western Poland. They are distinguished by a diverse hydromorphology of watercourse beds dynamically shaped by a strong current, with gravel-bed sections and erosion processes of banks. These watercourses are fed by groundwater outflows and the whole area is characterised by abundance of springs. Phytocoenoses from the Ranunculion fluitantis Neuhäusl 1959 alliance identifying this habitat are often of ephemeral nature and sensitivity to water quality changes, suspensions limiting access of plants to light and unstable flow points to their indicator character (Puchalski 2004; Szoszkiewicz \& Gebler 2012; Matuszkiewicz 2013; Szpikowski et al. 2016).

One of the species associated with water-crowfoot river habitat, which as a result of complex anthropopressure disappeared in Western Pomerania in late 1980s, was $G$. densa of the family Potamogetonaceae. It is an evergreen species with densely leafy and poorly branched shoots completely submerged in water. It occurs in watercourses of varying intensity of flow, nowadays, rarely in still waters, although scientific data from 1960s suggest a fairly common occurrence of this plant in ponds with underground supply, then common in trout breeding (Berantowicz \& Wolny 1969). Spread in the northern hemisphere, the $G$. densa population in Europe has been preserved in Alpine and subalpine areas, although in many countries (Denmark, Lithuania, Great Britain), it is considered an extinct taxon (Duygu \& Kadiriye 2011; Akhani 2014; Żukowski 2014; Puchalski et al. 2016) (Fig. 1). In Poland, it is a species under strict legal protection and requires active protection in accordance with the Regulation of the Minister of Environment of 9 October 2014 on plant species protection (Official Journal of October 16, 2014, item 1409). It is also critically endangered and placed on the Polish Red List of ferns and flowering plants 


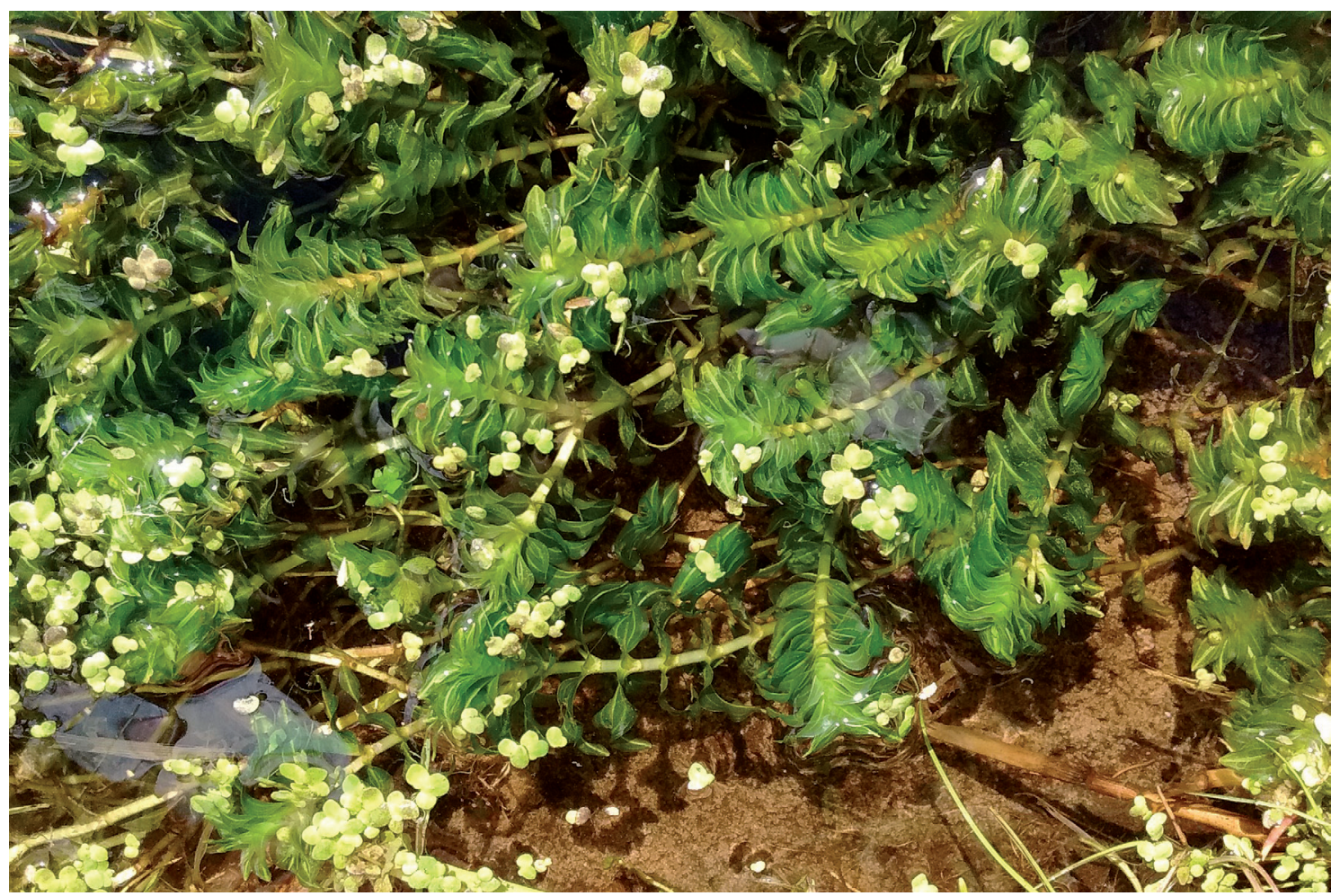

Fig. 1. Reintroduced population of Groenlandia densa (L.) Fourr. (photo by M. Wróbel)

(Kaźmierczakowa et al. 2016) and in the Polish Red Book of Plants (Kaźmierczakowa et al. 2014). The decision to reintroduce $G$. densa was based on the idea of restoring the species to its former historical site and was an attempt to save the plant species diversity of rivers with Ranunculion fluitantis communities. The inclusion of this species, historically occurring in Western Pomerania, in the group of taxa particularly endangered in the flora of Poland and taken into account in future restitution activities, was an argument for trying its reintroduction (Ziarnek 2017).

The aim of research was to assess the adaptability of $G$. densa, a critically endangered species reintroduced to historical sites, characterise threats affecting the effectiveness of reintroduction, and asses habitat conditions at the sites of successful reintroduction.

\section{Materials and methods}

The natural habitat of water-crowfoot rivers (3260) constitutes one of the subjects of protection activities in the LifeDrawaPl project called "Active protection of water-crowfoot habitat and the restoration of the wildlife corridor in the River Drawa basin in Poland" implemented in years 2014-2020. As part of protection activities, G. densa population, historically occurring in these areas and related to water-crowfoot river habitat, was reintroduced. The reintroduction of G. densa was preceded by multiplication and acclimatization of biological material from twin genetic populations from subalpine and Alpine regions of Bavaria and Austria. Previously, genetic tests confirming its high affinity to the population historically present in Poland until the end of 1980s were performed. The source material which served as a reference for the genetic testing, was the historical herbal herbaceous collection of that species (Puchalski et al. 2016). Habitat requirements of the species in terms of its acclimatization and further multiplication were met by watercourses located at the Adam Mickiewicz University in Poznań: in the Botanical Garden in Poznań and the Geoecological Station of AMU in Storkowo (Grzmiąca commune, Szczecinek district, West Pomeranian Voivodeship). These two centers provided an adequate number of specimens for resettlement, while maintaining permanent breeding to safeguard the ex situ primary population for research and supplementary resettlement. Reintroduction sites were examined to obtain information regarding source materials on historical sites and field visions in Grabowa and Radew rivers in the Natura 2000 areas, PLH 320022 "Radew, Chociela and Chotla Valley" and PLH 320003 "Grabowa Valley". Sections of watercourses with good light conditions, with gravel-stone bottom, rapid current, surrounded by springs confirming the supply of selected watercourses with underground waters were investigated (Fig. 2).

Subsequent stages verified site selection correctness conducive to acclimatization of the reintroduced 


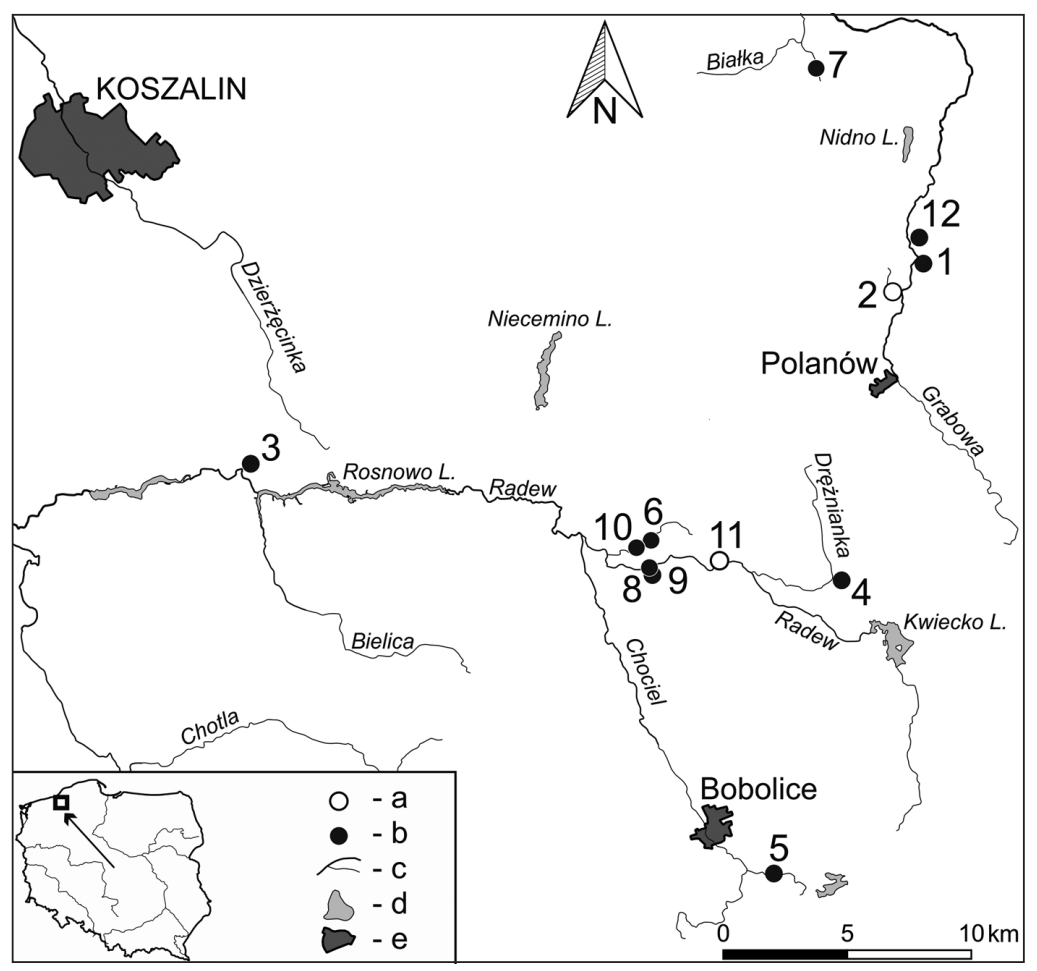

Fig. 2. Localization of monitored reintroduction sites of Groenlandia densa in the Grabowa, Radew and Chociel rivers (Western Pomerania) Explanations: $\mathrm{a}$ - unsuccessful reintroduction sites, $\mathrm{b}$ - active reintroduction sites, $\mathrm{c}$ - watercourses, streams, $\mathrm{d}-$ lakes, $\mathrm{e}$ - built up areas

G. densa specimens and the efficiency of resettlement increased. The material taken from breeding sites was transported in thermal containers, trying to maintain a stable water temperature $\left(10-14^{\circ} \mathrm{C}\right)$ and the resettlement was carried out on the day the material was taken so that plants did not experience thermal shock. G. den$s a$ shoots, on average, $2-30 \mathrm{~cm}$ long, were combined in bundles of 50 and fixed at the bottom of the watercourse, usually at the edge of the current, closer to the bank with bamboo sticks. When gravel-stone substrate was available, specimens were reinforced with stone or gravel to make it easier for them to root in the bottom. A total of 6,000 specimens of $G$. densa were resettled or replenished at 33 sites in three stages of reintroduction carried out between 2017-2018. Regular monitoring of the sites carried out in years 2018-2020 made it possible to assess success of these treatments and determine main threats or causes of failure (Table 1). Phytosociological relevés were taken using the Braun-Blanquet method, determining only the participation of species in patches of the identified phytocoenoses, using a 5-stage coverage scale. Names of plant communities were given according to Matuszkiewicz (2013) and Ratyńska et al. (2010), names of vascular plant species - according to Mirek et al. (2002) and Rutkowski (2004).

At each reintroduction site, parameters of the habitat that may have affected the adaptation of $G$. densa specimens were described, such as: watercourse depth, water temperature, water flow intensity, water flow stability, shading, gnawing by animals, presence of organic sedi-

Table 1. The effectiveness of the reintroduction program of Groenlandia densa (L.) Fourr in the following years 2017-2020

\begin{tabular}{cccc}
\hline $\begin{array}{c}\text { Stages of reintroduction of } \\
\text { Groenlandia densa }\end{array}$ & I stage & II stage & III stage \\
& $07-08.2012$ & $10-11.2017$ & $07-09.2018$ \\
\hline Number of shoots/seedlings & 400 & 1000 & 4600 \\
Number of reintroduction sites & 12 & 5 & 16 \\
\hline Monitoring the effects of reintroduction - number / percentage of retained sites with Groenlandia densa \\
\hline 2018 & $3(25 \%)$ & $1(20 \%)$ & $9(56 \%)$ \\
2019 & $2(20 \%)$ & $1(20 \%)$ & $7(44 \%)$ \\
2020 & $2(20 \%)$ & $1(20 \%)$ & $6(38 \%)$ \\
\hline
\end{tabular}


Table 2. Phytocoenoses from the Ranunculion fluitantis alliance in the Grabowa, Radew and Chociel rivers at sites of reintroduction of Groenlandia densa (L.) Fourr

\begin{tabular}{|c|c|c|c|c|c|c|c|c|c|c|c|c|}
\hline $\begin{array}{l}\text { Number of } \\
\text { reintroduction site }\end{array}$ & 7 & 8 & 9 & 1 & 5 & 10 & 6 & 12 & 4 & 3 & 2 & 11 \\
\hline Localization & $\mathrm{B}$ & $\mathrm{K} 1$ & $\mathrm{~K} 2$ & W4 & CB2 & $\mathrm{WC}$ & ZS6 & W2 & $\mathrm{D}$ & SR & $\mathrm{B} 1$ & $\dot{Z}$ \\
\hline Year & 2019 & 2019 & 2019 & 2018 & 2018 & 2018 & 2020 & 2019 & 2019 & 2019 & 2020 & 2020 \\
\hline Area of record $\left[\mathrm{m}^{2}\right]$ & 10 & 15 & 5 & 10 & 10 & 10 & 20 & 5 & 10 & 50 & 25 & 100 \\
\hline $\begin{array}{l}\text { Cover of emerged } \\
\text { vegetation }[\%]\end{array}$ & 10 & 20 & 30 & 20 & 35 & 5 & 20 & 25 & 35 & 20 & 40 & 10 \\
\hline $\begin{array}{l}\text { Cover of submerged } \\
\text { vegetation }[\%]\end{array}$ & 40 & 30 & 40 & 40 & 20 & 30 & 15 & 35 & 40 & 70 & 25 & 20 \\
\hline \multicolumn{13}{|l|}{ Habitat parameters } \\
\hline water flow intensity & avg & avg & high & high & high & high & high & high & low & avg & high & avg \\
\hline water flow stability & high & high & avg & high & high & low & avg & avg & avg & high & low & low \\
\hline water course depth [m] & 0,08 & 0,25 & 0,55 & 0,11 & 0,17 & 0,4 & 0,25 & 0,11 & 0,11 & 0,11 & 0,27 & 0,08 \\
\hline gnawing & none & none & none & per & per & syst & per & syst & per & none & per & per \\
\hline shading & avg & avg & none & per & per & none & none & per & per & per & per & per \\
\hline organic sediments & none & little & none & none & none & none & none & little & little & little & none & none \\
\hline bottom structure & grav & grav & sand & grav & grav & sand & sand & sand & sand & grav & sand & sand \\
\hline competing species $[\%]$ & 10 & 10 & 30 & 30 & 20 & 50 & 20 & 40 & 30 & 30 & 20 & 50 \\
\hline surface with G.densa $\left[\mathrm{m}^{2}\right]$ & 4 & 1 & 0,5 & 0,5 & 0,5 & 0,5 & 1 & 0 & 1 & 9 & 0 & 0 \\
\hline habitat state assessment & $\mathrm{FV}$ & FV & U1 & $\mathrm{U} 2$ & U1 & $\mathrm{U} 2$ & U1 & $\mathrm{U} 2$ & U1 & FV & $\mathrm{U} 2$ & $\mathrm{U} 2$ \\
\hline water temp. $\left[{ }^{\circ} \mathrm{C}\right]$ & 10,5 & 11,2 & 10,8 & 10,2 & 10,2 & 10,2 & 9,6 & 10,3 & 11,2 & 10,9 & 11,5 & 10,3 \\
\hline number of species & 8 & 9 & 8 & 8 & 7 & 5 & 8 & 7 & 7 & 9 & 8 & 6 \\
\hline \multicolumn{13}{|c|}{ ChD*Ass. Beruletum submersae } \\
\hline Berula erecta f.submersa & 2 & 1 & 3 & 3 & 2 & 2 & 1 & 3 & 2 & 1 & 2 & + \\
\hline Berula erecta f.emersa & 1 & 1 & 2 & 1 & 2 & 1 & 1 & 2 & 2 & 2 & 2 & 1 \\
\hline $\begin{array}{l}\text { Veronica anagallis- } \\
\text { aquatica f.submersa }\end{array}$ & 1 & 2 & + & 1 & + & . & + & + & 1 & 1 & + & . \\
\hline Nasturtium officinale* & 1 & 1 & + & . & . & . & + & . & . & . & . & . \\
\hline \multicolumn{13}{|c|}{ ChAss. Ranunculetum fluitantis } \\
\hline Ranunuculus fluitans & & & . & . & . & . & . & . & . & . & . & 2 \\
\hline \multicolumn{13}{|c|}{ ChAll. Ranunculion fluitantis * et Cl. Potametea } \\
\hline Groenlandia densa * & 2 & 1 & + & 1 & 1 & + & 1 & . & 1 & 3 & . & . \\
\hline Sparganium erectum & . & . & . & . & + & . & 1 & . & . & 1 & 2 & 1 \\
\hline Veronica becabunga & + & 1 & + & 1 & 2 & + & 1 & 1 & 2 & + & 1 & + \\
\hline Potamogeton crispus & . & . & . & . & . & . & . & . & . & 2 & 1 & 2 \\
\hline Elodea canadensis & . & . & . & . & . & . & 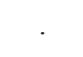 & . & . & 2 & 1 & . \\
\hline \multicolumn{13}{|l|}{ Accompanying species } \\
\hline Lemna minor & 1 & + & 1 & 1 & + & 1 & 1 & + & 1 & 1 & + & + \\
\hline Lemna trisulca & 2 & 1 & + & + & . & 2 & . & 1 & 2 & . & . & . \\
\hline Hildebrandia rivularis & + & + & . & + & . & . & . & . & . & . & . & . \\
\hline Glyceria fluitans & . & + & 2 & 1 & 2 & . & 1 & 1 & 2 & 1 & 2 & \\
\hline
\end{tabular}

Explanations: B - Biegała, K1 - Kurowo 1, K2 - Kurowo 2, W4 - Wieleń 4, CB2 - Chociel koło Bobolic 2, WC- Węglanowy Ciek, ZS6 - Zgniła Struga 6, W2 - Wieleń 2, D - Drężnianka koło Lubowa, SR - Stara Radew, Bł - Błotnica, Ż - Żabiniec, Qr - water flow intensity, per - periodic, syst - systematic, avg - average, temp - temperaturę, grav - gravel, FV - favourable, U1 - inadequate, U2 - bad

ments and structure of the watercourse bottom. Percentage of competing species, the surface of $G$. densa, and overall assessment of habitat condition were also taken into account according to the methodology of Chief Inspectorate of Environmental Protection (Table 2) (Szoszkiewicz \& Gebler 2012). No external threats of anthropogenic origin, such as devastation, accidental destruction, etc., were identified for the analyzed reintroduction sites.
The data used for statistical analyzes were of ordinal nature, excluding parameters such as average depth of the watercourse, temperature, and the percentage of competing species, which were numerical. To initially identify the species preferences for the habitat, the redundancy analysis was carried out using the CANOCO 4.5 (Lepš \& Šmilauer 2003). 


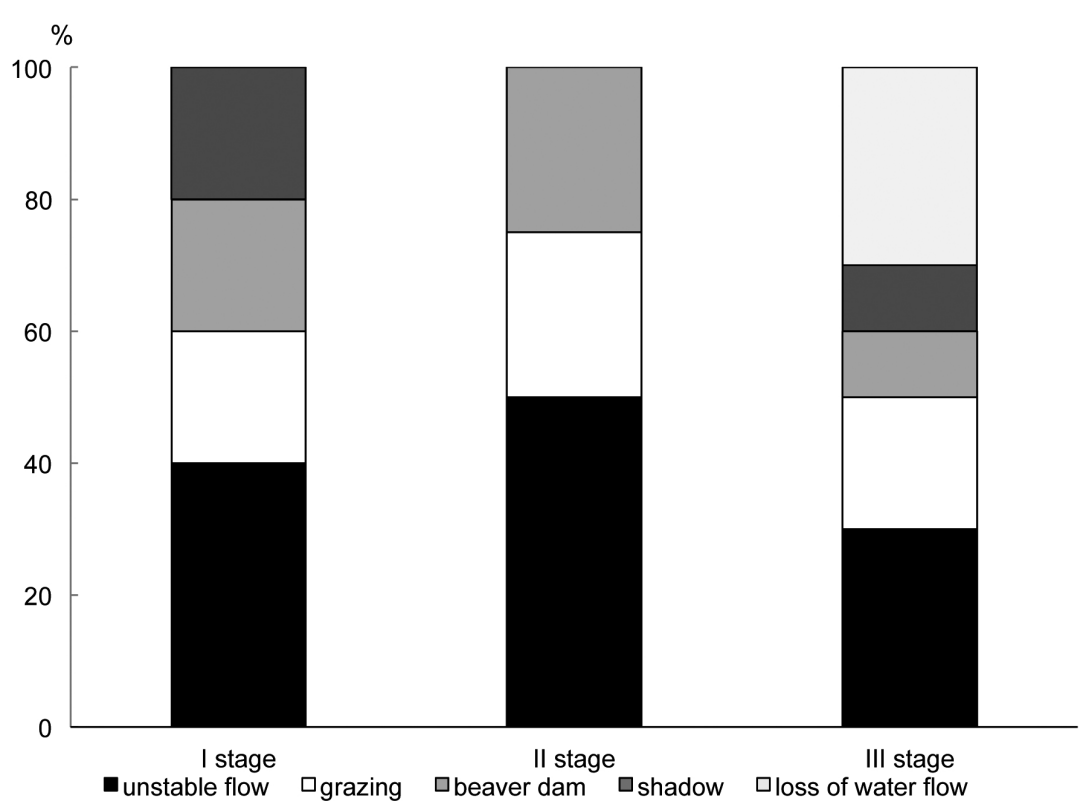

Fig. 3. Reasons for diminishing of Groenlandia densa population, reintroduced in stages I-III (in the years 2017-2018) on 33 sites. The state of preservation of sites in 2020

\section{Results}

Unstable flows, including flood waves after heavy rainfall, destabilizing and transforming sandy-muddy bottoms of watercourse beds with resettled $G$. densa, were in $30-50 \%$ responsible for destruction of sites in subsequent stages of reintroduction (Fig. 3). Seasonindependent feeding of animals (in winter in search of food and in summer during wandering through beds of drying watercourses) destroyed $20-25 \%$ of the sites. Beaver dams partitioned even small watercourses, created stagnation, and with the increase in water temperature, accumulation of sediments, siltation of the bottom, and deterioration of water transparency caused losses ranging from $10-25 \%$ as the settled $G$. densa did not tolerate such conditions. Closing of light gaps in tree crowns and increase in shade was another factor found to have a destructive effect on the settled specimens (10$20 \%$ of lost sites). The factor that irreversibly destroyed sites in 2019 (30\% of the lost sites from the third stage of reintroduction) was cessation of underground water supply or its significant reduction preventing vegetation of $G$. densa specimens when water level fell below $5 \mathrm{~cm}$. This was due to persistent hydrological drought. Significantly reduced water supply caused an increase in the thermal gradient of the water, resulting in dying out of plant shoots. There was also another factor limiting the supply of watercourses, i.e., invasion of a common yellow monkeyflower, Mimulus guttatus Fisch., with $100 \%$ coverage of springs of Biegała, Błotnica or Zielenica rivers (tributaries of the Grabowa river) within only 3 seasons from the first specimens of this plant found. In total, about $20 \mathrm{~m}^{2}$ of $G$. densa patches were obtained from all sites, achieving the success of this treatment at the level of $26 \%$.

Monitoring of $G$. densa reintroduction sites also included habitat state assessment according to the methodology of the Chief Inspectorate of Environmental Protection, including recognition of phytocoenoses, identifying the natural habitat of water-crowfoot rivers. It was found that on 12 sites covered by permanent monitoring, where $G$. densa was maintained until the end of 2019, there was an initial habitat form of watercrowfoot river identified by the Beruletum submersae Roll 1938 community, occurring almost exclusively in the upper spring sections of Grabowa, Radew, Chociel rivers and their tributaries. These sections were distinguished by stable, often intensive water flow and presence of numerous underground seepages. Although they were relatively shallow $(10-25 \mathrm{~cm})$, their bottom had a differentiated morphology, typical of naturally meandering gravel-stone watercourses, with clearly marked zones of sequences of uplifted rapids, with a rapid flow, and relatively deeper, calmer zones with slightly slower flows (Fig. 4). On shaded sections flowing in riparian forests, on stony bottom, protected freshwater red algae Hildebrandia rivularis (Liebm.) J. Agardh and water moss Fontinalis antipyretica Hedw were found to occur. Lack of light was a limiting factor in the development of Groenlandia densa, therefore it was resettled to sites with good light access where patches of Beruletum submersae Roll 1938 community developed. Finally, these sites proved to be the most favorable to its habitat requirements and $G$. densa survived only on these sites 


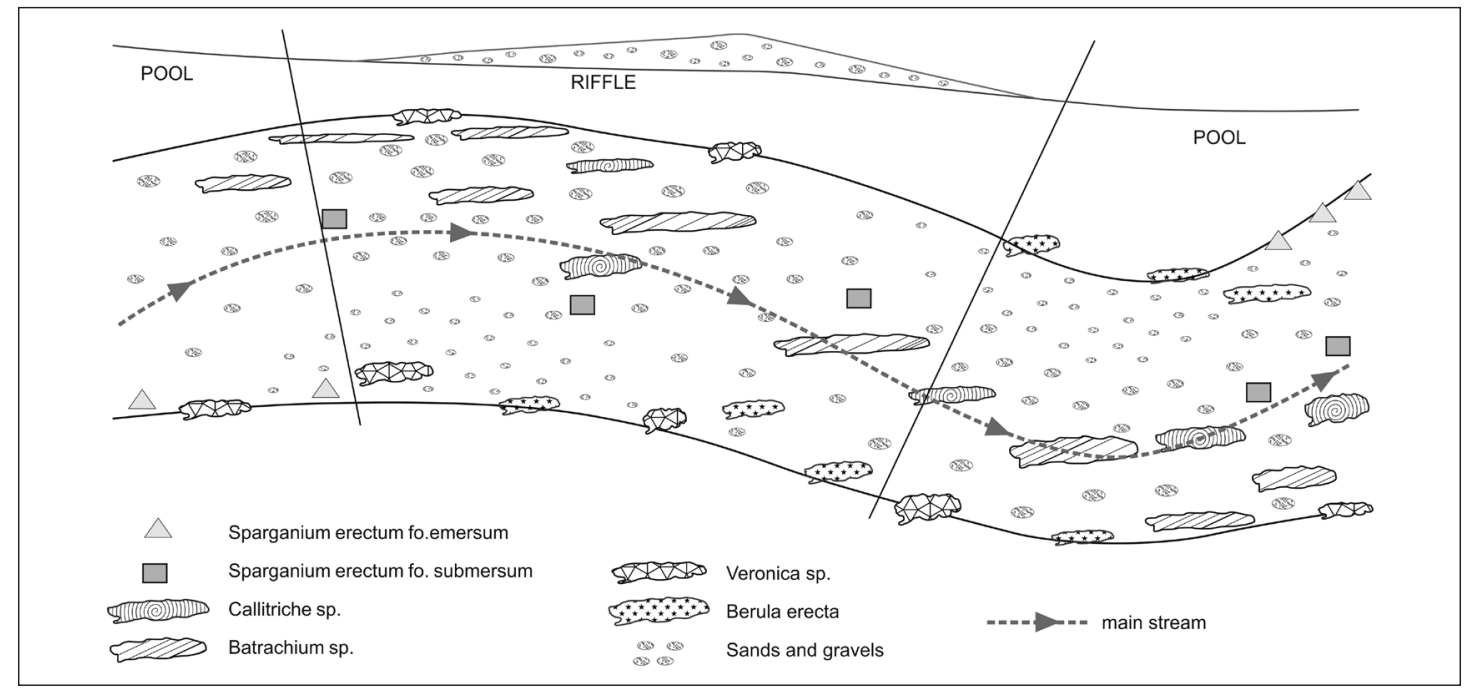

Fig. 4. Distribution of plant patches from the Ranunculion fluitantis alliance in a naturally diversified gravel bed

(Table 2). Berula erecta Hudson (Coville) f. submersa dominated in patches of this species-poor community, keeping underwater evergreen leaves even in winter. It was accompanied by Veronica anagallis-aquatica L. and $V$. beccabunga L. while Nasturtium officinale R.Br. appeared abundantly on sites near springs. The full form of water-crowfoot river habitat with participation of Batrachium sp. developed fragmentarily further away from springs of these watercourses, with good light, fast currents and sections with gravel beds preserved. Other species characteristic of the Ranunculion fluitantis Neuhäusl, 1959 alliance, including Sparganium erectum L. emend. Rchb. s. str. f. submersa or Potametea R.Tx. et Prsg 1942 ex Oberd. 1957 class-specific species such as Potamogeton crispus L. or Elodea canadensis
Michx. were observed there. Such sites were assumed to meet habitat requirements of $G$. densa and were also selected as sites for its reintroduction. Unfortunately, transformation of beds of selected watercourses, notch of the bed, and the resulting loss of communication with flood terrace due to anthropogenic changes, sometimes decades ago, sometimes contemporary, caused instability of flows in them, appearance of strong turbidity at swelling, which altogether did not allow the plant to stay for more than a few weeks from planting (Figs 5-6).

Preliminary statistical analysis using redundancy analysis (RDA) showed presence of a clear gradient along the $\mathrm{Y}$ axis (Fig. 7). It revealed a strong correlation between sites 3,7 , and 8 and population status assessment, surface of $G$. densa, and environmental

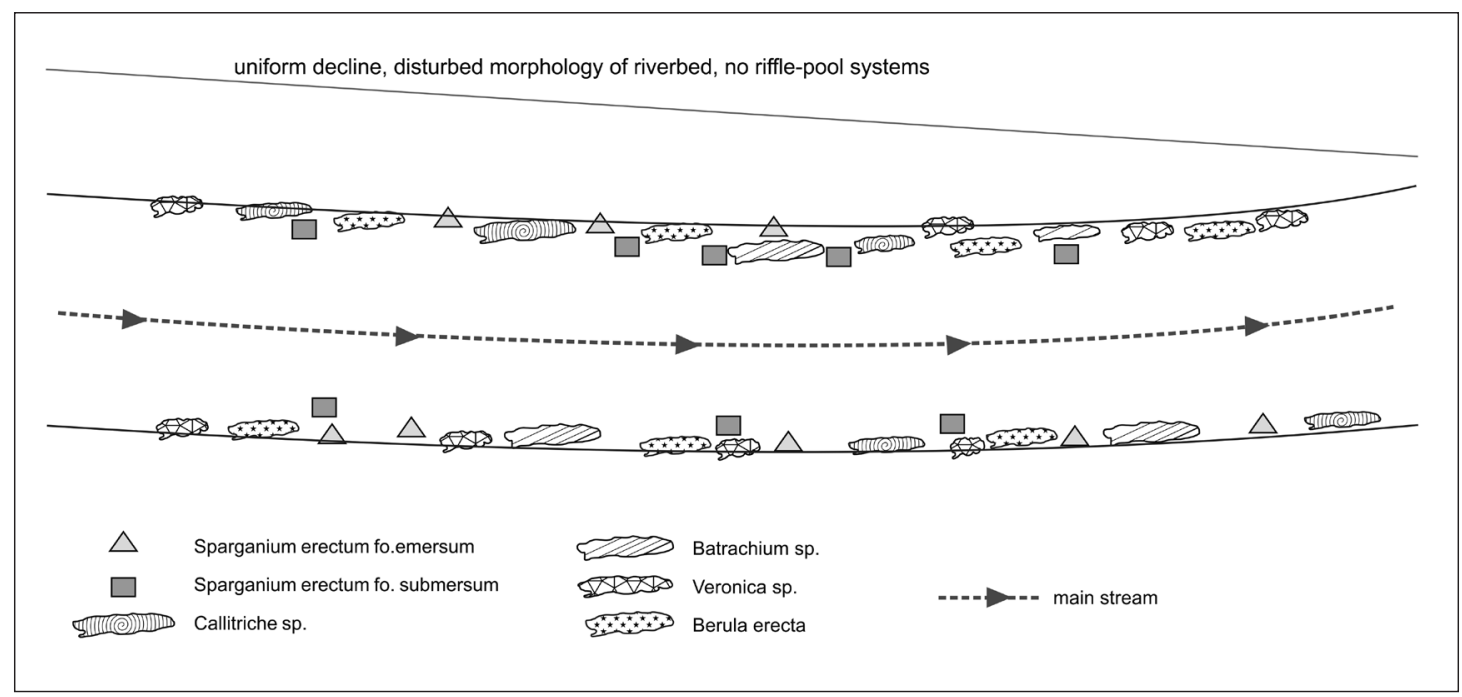

Fig. 5. Distribution of plant patches from the Ranunculion fluitantis alliance in a regulated river bed. Specimens of Batrachium sp., if any, are usually located near the edges of bank slopes, where groundwater effusions occur 


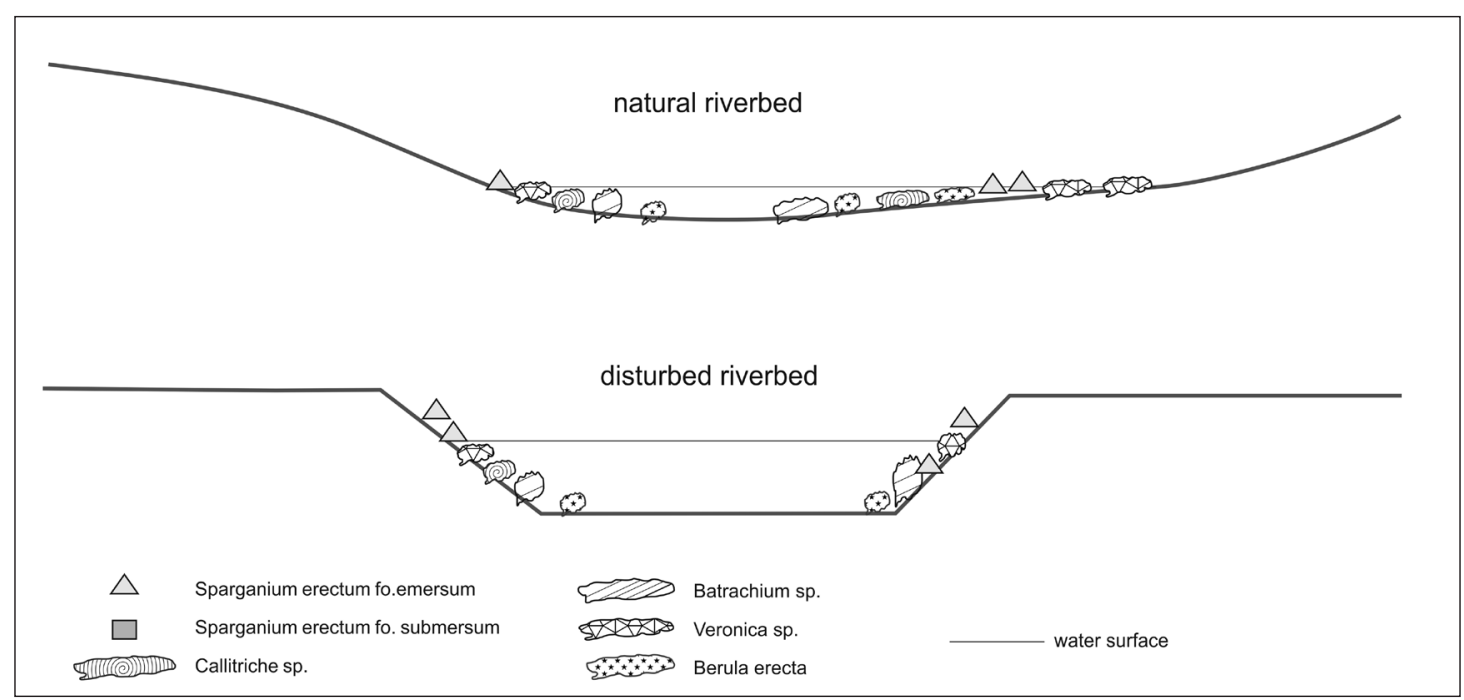

Fig. 6. Comparison of the layout of plant patches from the Ranunculion fluitantis alliance in the vertical profiles of disturbed and natural riverbeds

parameters such as: water depth, water temperature, water flow intensity, bottom structure, and participation of competing species. It revealed a weaker correlation between the above-mentioned and external threats. There was also a clear gradient along the $\mathrm{X}$ axis, correlated with presence of competing species and reintroduction site No. 11. A strong correlation between sites No. 2 and 12 , and gnawing and shading was recorded.

\section{Discussion}

The relationship between successful reintroduction of $G$. densa and location of resettlement sites in patches of the Beruletum submersae Roll 1938 community is not only an important indication for renaturation activities, water maintenance or active protection of endangered species, but also indicates a bioindication role of river

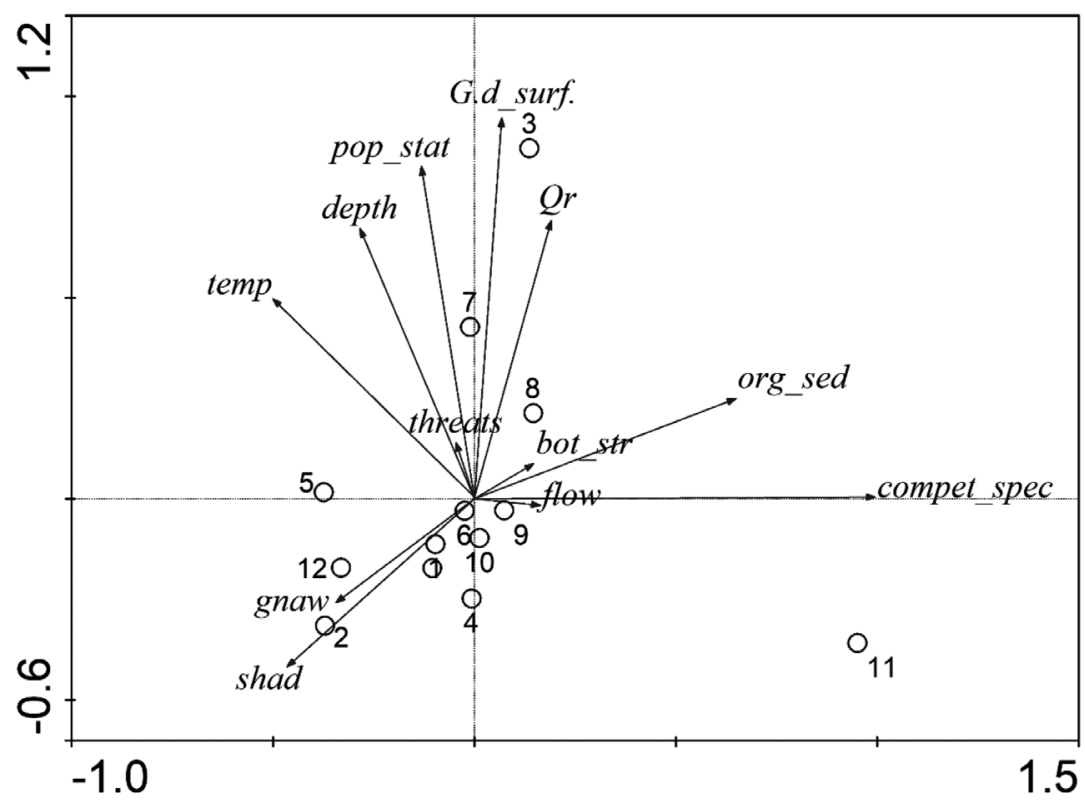

Fig. 7. Diagram of the results of redundancy analysis (RDA)

Explanations: G.d surf - the area of G. densa population $\left[\mathrm{m}^{2}\right]$, pop stat - population status assessment [in scale 1-3, where 1-FV, 2 - U1, 3- U2], Qr - water flow intensity [in scale 1-3, where 0 - no flow, 2 - small flow, 3 - large flow], flow - water flow stability [in scale 0 - stable, 1 - changeable], depth - water course depth [m], gnaw - gnawing [in scale $0-4$, where 0 - no gnawing, 4 - great gnawing], shad - shading, temp - water temperature [ ${ }^{\circ} \mathrm{C}$ ], org sed - organic sediments [in scale $0-3$, where 0 - no sediments, 3 - a lot of sediments], bot_str - bottom structure [in scale 1-4, where 1 - gravel-stone, 2 - sand, 3- sandgravel, 4-sand-gravel-stone], compet spec - competing species [percentage coverage of competing species in the studied sites], threats - external threats of anthropogenic origin [as the number of total threats] 
phytocoenoses of macrohydrophytes in the comprehensive assessment of biotic and abiotic elements of the river ecosystem (Henry et al. 1996; Elger et al. 2004; Tarkowska-Kukuryk \& Mieczan 2017). An example is the habitat of 3260 lowland and submountain rivers with water-crowfoot (Ranunculion fluitantis) communities, the initial form of which occurs almost exclusively in the upper, spring sections of watercourses feeding the Grabowa and Radew river systems, and was conducive to the reintroduction of $G$. densa, a critically endangered species associated with this habitat and practically not recorded in Poland for over 30 years. The presence of this poor combination of species initiates a whole sequence of plant communities defining the habitat of water-crowfoot river, usually fully developed only in lower sections of the river, with a wider riverbed, still fast flow, stable gravel-stone bottom and constant light access. However, such places with the ecological status of waters - mainly the level of nutrients - satisfactory for the requirements of the Batrachium sp. water-crowfoots are increasingly rare.

Beds of vast majority of the examined watercourses underwent significant anthropogenic transformations, often almost from springs, as a result of agricultural use of areas adjacent to the river, without sufficient buffer zones limiting the runoff of dust and clay fractions or fertilizers and plant protection products. An additional shortcoming found in the area of reintroduction activities was the use of watercourses as fish-farming sites, which resulted in raising the level of suspended matter and water trophies of such watercourses from several to even several dozen times in relation to watercourses free of such facilities (Barrat-Segretain et al. 1998; Bonisławska et al. 2017). Groenlandia densa and Batrachium sp. are particularly sensitive to any changes in water fertility and reduction of its transparency. Their evergreen shoots submerged in current systematically filter water all year round, actively removing excess nutrients and some small suspensions. Exceeding critical levels of nitrogen and phosphorus compounds in the watercourse, increase in suspended matter, slowdown of the current and rapid drops in water level in the watercourse eliminate both these species (Greulich \& Bornette 1999; Greulich \& Bornette 2003; Puijalon et al. 2008).

Intensification of agriculture without maintaining effective buffer zones, resulting in excessive nutrient runoff and municipal pollution cause increase in the trophy of flowing waters and the amount of suspended matter. These suspensions are not only dusty and clayey fractions of leached soils, but also strong phytoplankton blooms, stimulated by significant levels of nutrients, equally effectively limiting the access of light.

The main causes of habitat disappearance are changes in catchment areas and water-crowfoot river beds resulting from anthropogenic transformations. Riverside communities benefited from the fertility of the valley, trying to get a wet, flooded part of the valley through drainage and trough regulation. Gravel sections were places where building material was obtained, and the rivers were often used for floating wood or even sailing for centuries. Together, these activities, to a certain extent continued today in the form of poorly understood maintenance of the bed permeability, led to a strong reduction in the diversity of the morphology of bed and bottom parts on which Batrachium sp. could develop. At the same time, the transverse construction of the watercourses, combined with regulation of a significant part of coastal river beds and their tributaries, first for supplying water mills, now for energy purposes, resulted in significant changes in annual flow cycles, leading to afforestation of flooded, originally wet valleys overgrown with meadow plant communities, riparian forests significantly limiting light access. In such sections, in spite of all ecological reasons, full composition of plants suitable for the habitat is not found due to lack of sufficient light (Barrat-Segretain 1996; Puijalon et al. 2008; Pawlaczyk 2017).

Unfortunately, observations concerning effects of changes, mainly of anthropogenic origin, that occurred in the last century and still occur in river basins confirm their difficult reversible influence on the weakening of underground supply and drying up of watercourses already in their upper parts. The consequences resulting from the drastic reconstruction of the river basin from springs to estuaries of the watercourses include strong hydrological imbalances in catchment areas of springs disturbing the stability of flows, intensification of droughts or floods with disastrous economic and social consequences. These changes also have a decisive impact on the conservation status of biodiversity in all groups of systematic water organisms and water or water-dependent natural habitats (Schütz 1995; Bornette \& Puijalon 2011; Bartnik \& Moniewski 2016; Bonisławska et al. 2017; Pawlaczyk 2017).

In this context, effects of unfavorable transformations of watercourses may be reduced in future within the framework of the undertaken restoration projects modeled on LIFEDrawaPL activities. On the other hand, they may, however, question the advisability of undertaking reintroduction treatments of other species, due to irreversible changes or loss of habitat with which they were associated.

\section{Conclusions}

1. An important element of the assessment of the potential of sites at the stage of their selection for the reintroduction of $G$. densa in coastal rivers is the state of preservation and diversity of rush-grassland 
vegetation and coastal riparian forest habitats. It constitutes a buffer limiting the inflow of nutrients from agricultural or municipal sources in the catchment area of the river and mitigates other forms of anthropopressure, which may reduce the assumed effects of reintroduction of species sensitive to changes in the trophy of flowing waters and the presence of suspended matter.

2. The assessment of the degree of transformation of the geomorphology of the river bed and valley in which reintroduction is expected is equally important, as only relatively preserved naturally meandering watercourses with zones of gravel-stone rise and calm areas can mitigate the unstable flows in watercourses and provide conditions for the development of river macrophytes in the Ranunculion fluitantis alliance.

3. Favorable conditions for reintroduction of $G$. densa occur in well-preserved Beruletum submersae Roll 1938 communities, in upper spring and gravel sections of rivers and their tributaries.
Acknowledgments. The work is the result of research carried out within the framework of the European project LIFE13 NAT / PL / 000009 "Active protection of water-crowfoot habitats and restoration of the wildlife corridor of the River Drawa basin in Poland". The authors thank the Regional Directorate for Environmental Protection in Szczecin for substantive support and organization of field work and the Botanical Garden of the Adam Mickiewicz University in Poznań and the Geoecological Station of the AMU in Storkowo for acclimatization and multiplication of Groenlandia densa specimens.

\section{Author Contributions}

Research concept and design: M. Wróbel

Acquisition and/or assembly of data: M. Wróbel, A. Furdyna Data analysis and interpretation: M. Wróbel, A. Furdyna, T. Miller

Drafting the article: M. Wróbel

Critical revision: M. Wróbel, A. Furdyna

Final approval: M. Wróbel

\section{References}

Akhani H. 2014. Groenlandia densa. The IUCN Red List of Threatened Species 2014: e.T164174A42321506. http://dx.doi.org/10.2305/IUCN.UK.2014-1.RLTS. T164174A42321506.en

Barrat-Segretain M. H., Bornette G. \& Hering-Vilas-Bôas A. 1998. Comparative abilities of vegetative regeneration among aquatic plants growing in disturbed habitats. Aquatic botany 60(3): 201-211. https://doi. org/10.1016/S0304-3770(97)00091-0

Barrat-Segretain M. H. 1996. Strategies of reproduction, dispersion, and competition in river plants: A Review. Vegetatio 123(1): 13-37. www.jstor.org/ stable/20048649

BARTNik A. \& Moniewski P. 2016. Changes in water quality of a small urban river triggered by deep drainage of a construction site. Journal of Water and Land Development. 31: 11-22. https://doi.org/10.1515/ jwld-2016-0032 https://doi.org/ 10.1515/jwld-20160016

Berantowicz S. \& Wolny P. 1969. Botanika rybacka. 420 pp. PWRiL, Warszawa.

BonisŁawska M., Nędzarek A., Rybczyk A., Czerniejewski P. \& Żuk B. 2017. Zmiany warunków abiotycznych małej rzeki z uwzględnieniem wpływu wód poprodukcyjnych z hodowli ryb. Woda-Środowisko-Obszary Wiejskie 17, 4(60): 5-23.

Bornette G. \& Puijalon S. 2011. Response of aquatic plants to abiotic factors: a review. Aquat Sci 73: 1-14. https:// doi.org/10.1007/s00027-010-0162-7

DuYGu Y. \& KadiRIYe U.P. 2011. Modelling the influence of salinity and water deficiency on the growth and biomass of Groenlandia densa (Potamogetonaceae). F. Environ. Bulletin. 20(7).
Elger A., Bornette G., Barrat-Segretain M. \& Amoros C. 2004. Disturbances as a structuring factor of plant palatability in aquatic communities. Ecology 85(2): 304-311. www.jstor.org/stable/3450196

Greulich S. \& Bornette G. 1999. Competitive abilities and related strategies in four aquatic plant species from an intermediately disturbed habitat. Freshwater Biology 41(3): 493-506. https://doi.org/10.1046/j. 1365-2427.1999.00395.X

Greulich S. \& Bornette G. 2003. Being evergreen in an aquatic habitat with attenuated seasonal contrast a major competitive advantage? Plant Ecology 167(1): 9-18. https://doi.org/10.1023/A:1023923418919

Henry C., Amoros C. \& Bornette G. 1996. Species traits and recolonization processes after flood disturbances in riverine macrophytes. Vegetatio 122(1): 13-27. www. jstor.org/stable/20048622

Kaźmierczakowa R., Zarzycki K. \& Mirek Z. (eds) 2014. Polish Red Data Book of Plants. Pteridophytes and flowering plants. III edition, $895 \mathrm{pp}$. Institute of Nature Conservation, Polish Academy of Sciences, Kraków.

Kaźmierczakowa R., Bloch-OrŁowska J., Celka Z., Cwener A., Dajdok Z., Michalska-Hejduk D., Pawlikowski P., SzczęŚniak E. \& Ziarnek K. 2016. Polish red list of pteridophytes and flowering plants. $44 \mathrm{pp}$. Instytut Ochrony Przyrody Polskiej Akademii Nauk, Kraków.

LEPŠ J. \& ŠMILAUER P. 2003. Multivariate analysis of ecological data using CANOCO. Cambridge University Press. https://doi.org/10.1017/CBO9780511615146

MatuszKiewicz W. 2013. Przewodnik do oznaczania zbiorowisk roślinnych Polski. In: J. B. FALIŃSKI (ed.). Vademecum Geobotanicum 3, 537 pp. III ed. Wyd. Nauk. PWN, Warszawa. 
Mirek Z., Piękoś-Mirkowa H., Zając A. \& Zając M. 2002. Flowering plants and pteridophytes of Poland. A checklist. In: Z. MireK (ed.). Biodiversity of Poland, 1, 442 pp. W. Szafer Institute of Botany, Polish Academy of Sciences, Kraków.

PAWLACZYK P. 2017. Ecological problems of river conservation in Polish Natura 2000 sites. Przegląd Przyrodniczy 28(4): 16-50.

Puchalski W. 2004. Nizinne i podgórskie rzeki ze zbiorowiskami włosieniczników. In: J. Herbich (ed.) Natura 2000 manual for the protection of habitats and species - methodological manual. Vol. 2. Fresh waters and peat bogs, pp. 96-108. Ministry of the Environment, Warszawa.

Puchalski W., Cieślak E., Nowak J. \& Żukowski W. 2016. Czy introdukcja Groenlandia densa (Potamogetonaceae) w Polsce ma szanse powodzenia? Fragm. Flor. Geobot. Polonica 23(2): 289-304.

Puijalon S., Piola F. \& Bornette G. 2008. Abiotic stresses increase plant regeneration ability. Evol Ecol (2008) 22: 493-506. https://doi.org/10.1007/s10682-007-9177-5

RatyŃSKa H., Wojterska M. \& Brzeg A. 2010. Multimedialna encyklopedia zbiorowisk roślinnych Polski. Uniwersytet Kazimierza Wielkiego, Bydgoszcz, wyd. multimedialne CD.

Regulation of the Polish Minister of Environment of October 9, 2014, on the protection for species of plants (Official Journal of October 16, 2014, item 1409)

RutKowski L. 2004. Klucz do oznaczania roślin naczyniowych Polski niżowej. II edition, 814 pp. Wyd. Nauk. PWN, Warszawa.

SchÜTZ W. 1995. Vegetation of running waters in Southwestern Germany - pristine conditions and human im- pact. Acta Botanica Gallica 142(6): 571-584. https:// doi.org/10.1080/12538078.1995.10515281

Szoszkiewicz K. \& Gebler D. 2012. Nizinne i podgórskie rzeki ze zbiorowiskami włosieniczników. In: W. Mróz (ed.). Monitoring of natural habitats. Methodical guide. Part 2, GIOŚ, pp. 204-217. Warszawa.

SzPikowski J., Piotrowicz R. \& SzPIKowska G. 2016. Raport z zadania "Monitoring hydrodynamiki fluwialnej dolin rzecznych oraz warunków siedliskowych dla rozwoju roślinności wodnej ze związku Ranunculion fluitantis z jej aktualnym stanem". Manuskrypt dla RDOŚ w Szczecinie, w tamach projektu LIFE13 NAT/ PL/0009 LIFEDrawa PL: 329. http://drawalifeplus. rdos.szczecin.pl/index.php/pl/raporty-z-realizacji/

Tarkowska-Kukuryk M. \& Mieczan T. 2017. Submerged macrophytes as bioindicators of environmental conditions in shallow lakes in eastern Poland. Ann. Limnol. - Int. J. Lim. 53: 27-34. https://doi.org/10.1051/ $\operatorname{limn} / 2016031$

ZiARNeK K. 2017. Potrzeba restytucji wybranych gatunków roślin zagrożonych wyginięciem w celu wzmocnienia ich dziko występujących populacji wraz z analizą zasobów ogrodów botanicznych pod kątem posiadania tych gatunków. GDOŚ w Warszawie, Lonicera, Szczecin.

Żukowski W. 2014. CR Groenlandia densa (L.) Fourr., Rdestniczka gęsta (rdestnica gęsta, grenlandia gęsta). In: R. Kaźmierczakowa, K. Zarzycki \& Mirek Z. (eds). Polish Red Data Book of Plants: Pteridophytes and Flowering Plants, pp. 574-575. Institute of Nature Conservation, Polish Academy of Sciences, Kraków. 